Jurnal_ep, Vol. 11 No. 1, Maret 2021

\title{
PENGEMBANGAN INSTRUMEN HASIL BELAJAR IPA DAN KEMAMPUAN METAKOGNITIF SISWA KELAS V SD
}

\author{
N.K.A. Sutami ${ }^{1}$, N. Dantes ${ }^{2}$, I.B.P. Arnyana ${ }^{3}$ \\ ${ }^{123}$ Program Studi Pendidikan Dasar \\ Universitas Pendidikan Ganesha \\ Singaraja, Indonesia \\ e-mail: ayu.sutami@pasca.undiksha.ac.id ${ }^{1}$, nyoman.dantes@pasca.undiksha.ac.id ${ }^{2}$, \\ putu.aryana@pasca.undiksha.ac.id ${ }^{3}$
}

\begin{abstract}
Abstrak
Penelitian ini bertujuan untuk mengembangkan instrumen hasil belajar IPA dan instrumen kemampuan metakognitif pada siswa kelas V SD yang valid dan reliabel. Penelitian ini menggunakan rancangan penelitian dan pengembangan dengan model 4-D. Model ini terdiri atas empat tahap utama yaitu define, design, develop, dan disseminate. Hasil penelitian ini yaitu, (1) Pada tahap define, telah disusunnya kisikisi instrumen hasil belajar IPA dan kisi-kisi instrumen kemampuan metakognitif. (2) Pada tahap design, kisi-kisi tersebut dijabarkan menjadi instrumen hasil belajar IPA berupa tes pilihan ganda yang pada awalnya terdiri dari 55 butir soal serta instrumen kemampuan metakognitif berupa tes esai yang pada awalnya terdiri dari 30 butir soal. (3) Pada tahap develop, telah dilakukan uji validitas isi instrumen hasil belajar IPA mendapatkan hasil sebanyak 50 butir soal dinyatakan valid. Uji validitas isi instrumen kemampuan metakognitif mendapatkan hasil sebanyak 25 butir soal dinyatakan valid. Kemudian uji reliabilitas instrumen hasil belajar IPA memperoleh hasil $r_{11} 0,82 \geq 0,70$, maka instrumen hasil belajar IPA dinyatakan reliable. Uji reliabilitas instrumen kemampuan metakognitif memperoleh hasil $r_{11} 0,78 \geq$ 0,70 , maka instrumen kemampuan metakognitif dinyatakan reliable. Dengan demikian pengembangan instrumen hasil belajar IPA dan kemampuan metakognitif dalam penelitian ini dinyatakan valid dan reliabel serta dapat dijadikan contoh untuk mengukur serta mengembangkan instrumen hasil belajar IPA dan instrumen kemampuan metakognitif siswa kelas V SD.
\end{abstract}

Kata kunci : Hasil Belajar IPA; Instrument; Kemampuan Metakognitif

\begin{abstract}
This study aimed at developing valid and reliable science learning result and metacognitive ability instruments of the fifth grade students. This study used research and development design. The development model used in this study was the 4-D development model which consists of four main stages namely define, design, develop and disseminate. The results of this study indicated some points. (1) At the define stage, forming the blue print of the science learning result instrument and metacognitive ability instrument (2) At the design stage, the blue prints are developed into science learning result instruments in the form of multiple choice tests which initially consisted of 55 items and metacognitive ability instruments in the form of of essay test which initially consisted of 30 items. (3) In the develop stage, it was found that the content validity test of the science learning result instruments and metacognitive ability instruments are valid. The reliability test of the science learning result instruments and metacognitive ability instruments are also reliable. Thus, the development of the science learning result and metacognitive ability instruments in this study conveyed valid and reliable. Thus, this study is able to be used as an example to measure and develop the science learning result instruments and metacognitive ability instruments of the fifth grade elementary school students.
\end{abstract}

Keywords: Science Learning Results; Instruments; Metacognitive Abilities 


\section{PENDAHULUAN}

Proses pendidikan di sekolah dasar bertujuan untuk memperoleh pengembangan pribadi anak dalam membangun dirinya serta mampu berperan bagi pembangunan nasional. Pendidikan akan berkualitas apabila terjadi penyelenggaraan pembelajaran yang efektif dan efisien dengan melibatkan semua komponen-komponen pendidikan. Komponen pendidikan meliputi kurikulum, guru, sarana prasarana, siswa, dan model pembelajaran yang tepat untuk meningkatkan mutu pendidikan. Dalam penyelenggaraan proses pendidikan formal di sekolah berpedoman dengan kurikulum untuk mencapai tujuan pendidikan yang telah ditetapkan.

Pedoman kurikulum yang digunakan saat ini yaitu Kurikulum 2013. Kurikulum 2013 mengusung keseimbangan antara kompetensi sikap (attitude), pengetahuan (knowledge), dan keterampilan (skill). Ketiga kompetensi tersebut diimplementasikan dalam seluruh muatan materi yang diberikan. Muatan materi pada Kurikulum 2013 di sekolah dasar terintegrasi pada pembelajaran tematik. Pembelajaran tematik memadukan muatan materi dalam suatu tema. Salah satu muatan materi pada pembelajaran tematik adalah IImu Pengetahuan Alam (IPA).

Berkenaan dengan kurikulum 2013, pembelajaran IPA di SD kelas I, II, dan III diintegrasikan pada muatan materi Bahasa Indonesia. Pada kelas VI, V, dan VI muatan materi IPA tersendiri melalui pembelajaran tematik terpadu. Pembelajaran IPA di SD. Kegiatan belajar IPA menekankan pemberian pengalaman langsung atau learning to do kepada siswa penting dilakukan untuk mengembangkan potensi yang dimiliki oleh siswa. Perlu disadari bahwa kemampuan berpikir siswa dalam belajar sangat penting dan harus dikembangkan. Udiani (2017) menyatakan bahwa kurangnya cara berpikir dan bekerja secara ilmiah dalam membentuk sendiri suatu konsep adalah faktor yang menyebabkan rendahnya hasil belajar IPA.

Berdasarkan hasil survey Programme for International Student Assesment (PISA) pada tahun 2015 Indonesia berada pada peringkat 64 dari 72 negara. Sedangkan hasil survery Trends in International Match and Science Survey (TIMSS) pada tahun 2015 Indonesia berada pada peringkat 45 dari 48 negara. Situasi tersebut menunjukkan bahwa siswa belum memiliki kemampuan berpikir tingkat tinggi. Rendahnya peringkat literasi sains di Indonesia belum sesuai dengan harapan. Kemampuan berpikir dalam muatan materi IPA masih cenderung mengingat, dan menyatakan kembali tanpa melakukan pengolahan informasi.

Aktivitas belajar siswa saat ini menuntut untuk mampu berpikir kritis. Menurut Sarini (2018) bahwa IPA memegang peranan penting dalam perkembangan intelektual anak yang dapat melatih siswa berpikir logis, rasional, kritis, dan kreatif. Sejalan dengan The Partnership for $21^{\text {st }}$ Century Skills yang merumuskan konten 4C (critical thinking, communication, collaboration, creativity). Kemampuan berpikir kritis merupakan kemampuan berpikir tingkat tinggi. Schraw \& Daniel (Nugroho, 2018) menyatakan bahwa salah satu kemampuan berpikir tingkat tinggi adalah kemampuan metakognitif. Menurut Wisudawati (2014) menyatakan bahwa IPA sebagai produk, pengetahuan IPA berupa pengetahuan metakognitif. Sejalan dengan Ilkram (2017) menyatakan bahwa dalam proses pembelajaran siswa yang mengembangkan kemampuan metakognitif akan mampu mengontrol diri lebih aktif diatas proses kognitifnya.

Kemampuan metakognitif siswa diperlukan dalam setiap muatan materi di sekolah. Muatan materi IImu Pengetahuan Alam (IPA) pada siswa harus diberikan pengalaman serta kesempatan untuk mengembangkan kemampuan berpikirnya terhadap alam. Kemampuan metakognitif pada muatan materi IPA sangat tepat diberikan karena siswa akan mengonstruk pelajaran melalui penalaran yang ia lakukan.

Pada proses belajar IPA, terdapat penilaian yang dilakukan guru sehingga menciptakan hasil belajar IPA. Hasil belajar IPA merupakan perubahan yang terjadi pada siswa sebagai akibat dari proses belajar IPA yang telah dilakukan. Dalam proses belajar IPA guru bukan hanya berperan untuk mengajar tetapi 
memfasilitasi siswa dalam memperoleh pemahaman terhadap materi. Pemahaman materi siswa selanjutnya menjadi kumpulan data dan informasi yang relevan sebagai penilaian guru. Kurikulum 2013 menerapkan penilaian autentik untuk menilai kemajuan belajar siswa yang meliputi sikap, pengetahuan, dan keterampilan. Alat penilaian yang digunakan guru untuk mengetahui ketercapaian belajar siswa yaitu instrumen.

Instrumen dalam pembelajaran di sekolah dipergunakan guru untuk mengukur dan menilai proses dan hasil pembelajaran yang telah dilakukan oleh siswa. Guru dapat menggunakan jenis-jenis instrumen yang relevan digunakan dalam proses pembelajaran. Jenis-jenis instrumen ada dua yaitu instrumen tes dan nontes. Intrumen tes digunakan untuk mengukur pengetahuan dan hasil belajar siswa sedangkan nontes menilai sikap dan kepribadian.

Upaya dalam mencapai tujuan pendidikan yang optimal salah satunya adalah kualitas instrumen yang digunakan oleh guru agar mampu mengembangkan kemampuan berpikir siswa. Namun kenyataannya, instrumen hasil belajar IPA yang digunakan guru terbatas pada bank soal maupun soal-soal latihan yang tersedia pada modul siswa. Guru lebih menekankan pada penguasaan konsep IPA dan belum dirancang untuk mengembangkan keterampilan berpikir tingkat tinggi. Instrumen yang telah tersedia tanpa adanya pengembangan oleh guru tersebut memiliki kualitas kurang baik. Kualitas kurang baik pada instrumen karena pada ranah kognitif Taksonomi Bloom Revisi terbatas pada C1 (mengetahui) dan C2 (memahami). Ini terbukti pada dari soal yang terdapat pada buku siswa tema 8 , contoh soalnya yaitu: "Sebutkan persyaratan air layak konsumsi!". Instrumen tersebut belum mampu memenuhi tagihan pembelajaran abad 21 pada bagian dari 4C yaitu critical thinking. Siswa menjadi terbiasa mengerjakan instrumen dengan kemampuan berpikir yang rendah.

Tuntutan zaman saat ini menjadikan seorang guru harus mengubah mindset tentang hasil pembelajaran dengan mencapai tujuan pembelajaran abad 21 .
Agar siswa mampu mencapai keterampilan Abad 21 maka guru harus memiliki instrumen yang relevan dengan memenuhi kebutuhan kemampuan berpikir siswa. Salah satu faktor yang dapat menimbulkan kemampuan berpikir rendah siswa dalam pembelajaran IPA adalah kualitas instrumen yang kurang baik. Oleh sebab itu perlu adanya pengembangan instrumen hasil belajar IPA dan untuk kemampuan berpikir tingkat tinggi siswa yaitu kemampuan metakognitif.

Dalam proses pendidikan, kompetensi siswa dijabarkan dalam bentuk indikatorindikator ketercapaian kompetensi. Ketercapaian kompetensi diperoleh melalui pengalaman belajar yang dirumuskan sebagai tujuan pembelajaran. Susanto (2016) menyatakan bahwa hasil belajar merupakan hasil dari kegiatan belajar melalui perubahan-perubahan yang menyangkut aspek kognitif, afektif dan psikomotor pada diri siswa. Siswa yang berhasil dalam belajar adalah siswa yang mencapai tujuan pembelajaran.

Pada hakikatnya IPA merupakan rumpun ilmu yang mempelajari tentang fenomena alam secara faktual sesuai dengan kejadian (reality) yang dapat menjelaskan hubungan sebab akibat (Wisudawati, 2014). Selajan dengan pendapat tersebut Jufri (2016) menyatakan bahwa IPA berorientasi pada fakta, konsep, prinsip, generalisasi, hukum, teori tentang alam yang menarik untuk dikaji, bermanfaat, selalu berkembang, dan berlaku global.

Muatan materi IPA diberikan mulai dari jenjang SD sampai jenjang sekolah menengah atas. Konsep IPA di sekolah dasar merupakan konsep yang terpadu dan terintegrasi melalui pembelajaran tematik (Susanto, 2016). Pada kelas awal IPA terintegrasi pada muatan materi Bahasa Indonesia. Sedangkan pada kelas tinggi tersendiri pada tema.

Muatan materi IPA di SD diharapkan dapat menjadi wahana bagi siswa untuk mempelajari diri sendiri dan alam sekitarnya. Septiasari (2020) menyatakan bahwa IPA merupakan proses belajar siswa mengenai alam dan sekitar. Pembelajaran IPA yang ideal adalah pembelajaran yang memberikan pengalaman langsung bagi anak (Rusniati, 2018:330). Pemberian 
pengalaman langsung untuk mengembangkan kompetensi agar menjelajahi dan memahami alam sekitar secara ilmiah. Sejalan dengan Udiani (2017) yang menyatakan bahwa pembelajaran IPA di SD lebih mementingkan penguasaan siswa terhadap proses dalam belajar. Siswa akan mendapatkan pengalaman langsung dari proses penemuan tersebut.

Secara historis, istilah kemampuan metakognitif diperkenalkan oleh Flavell (1976) yang diartikan sebagai kemampuan seseorang untuk mengontrol bermacammacam aktivitas kognitif. Kemampuan metakognitif merupakan cara seseorang menilai dirinya sendiri tentang kemampuan yang dimilikinya. Kemampuan metakognitif adalah kemampuan untuk menyadari, mengetahui, dan proses kognisi (pengenalan) yang terjadi pada diri sendiri. Anderson and Krathwohl Bloom's Taxonomy Revised (2016) menyatakan bahwa, Metacognitive Knowledge is the awareness of one's own cognition and particular cognitive processes. It is strategic or reflective knowledge about how to go about solving problems, cognitive tasks, to include contextual and conditional knowledge and knowledge of self.

Metakognitif adalah pengetahuan seseorang tentang proses berpikirnya sendiri, atau pengetahuan seseorang tentang kognisinya serta kemampuan dalam mengatur dan mengontrol aktivitas kognisinya dalam belajar dan berpikir (llkram, 2017:112). Wiryawati (2020) menyatakan bahwa metakognitif merupakan pengetahuan bagaimana suatu pembelajaran terjadi pada diri seseorang dengan mengedepankan kemampuan untuk berpikir tingkat tinggi. Dalam penelitian ini, teori dasar yang digunakan adalah sintesis teori Anderson and Krathwohl (2001) yang dirumuskan sebagai berikut. Definisi kemampuan metakognitif adalah kemampuan untuk mengontrol bermacammacam aktivitas kognitif, sehingga mampu menilai dirinya sendiri tentang kemampuan yang dimilikinya. Dalam penelitian ini, menggunakan dimensi kemampuan metakognitif yang dikemukakan oleh Anderson dan Krathwohl (2001) yaitu pengetahuan strategi (strategic knowledge), pengetahuan tentang tugas-tugas kognitif, termasuk pengetahuan kontekstual dan kondisional, dan pengetahuan diri (selfknowledge).

Dalam melaksanakan tugas seseorang memerlukan alat yang tepat sehingga dapat menyelesaikan tugas tersebut dengan baik. Jika alat yang digunakan tidak tepat dengan tugas yang dikerjakan maka alat tersebut belum dapat mencapai tujuan yang diinginkan. Instrumen dalam pendidikan digunakan sebagai instrumen evaluasi pembelajaran. Instrumen evaluasi pembelajaran merupakan alat yang digunakan oleh guru untuk mengevaluasi kegiatan belajar siswa dengan teknik tertentu. Instrumen dalam penelitian digunakan sebagai alat untuk mengukur variabel tertentu. Untuk mencapai tujuan secara efektif dan efisien instrumen harus baik sebagai alat ukur.

Pencapaian tujuan hasil belajar siswa dapat dilihat dari penguasaan materi yang telah diberikan melalui evaluasi baik dalam proses pembelajaran ataupun setelah pembelajaran selesai. Menurut Annisa (2017) menyatakan bahwa guru bertugas sebagai evaluator dalam melaksanakan evaluasi hasil belajar siswa dari segi pemahaman materi IPA yang meliputi aspek kognitif.

Untuk mencapai tujuan yang telah ditetapkan, perlu digunakan instrumen yang berkualitas. Instrumen yang berkualitas akan dapat menunjang penyelenggaraan evaluasi pembelajaran IPA yang berkualitas pula (Erniwati, 2018). Instrumen yang berkualitas adalah instrumen yang memenuhi pesyaratan instrumen yang baik. Adapun tujuan dalam penelitian ini adalah: (1) untuk mengetahui validitas isi instrumen hasil belajar IPA pada siswa kelas V SD. (2) untuk mengetahui validitas isi instrumen kemampuan metakognitif pada siswa kelas $V$ SD. (3) untuk mengetahui reliabilitas menurut expert instrumen hasil belajar IPA pada siswa kelas V SD. (4) untuk mengetahui reliabilitas menurut expert instrumen kemampuan metakognitif pada siswa kelas V SD.

\section{METODE}

Penelitian ini menggunakan rancangan penelitian pengembangan Jurnal Penelitian dan Evaluasi Pendidikan Indonesia | 54 
Research and Development. Produk yang dikembangkan berupa instrumen hasil belajar IPA dan instrumen kemampuan metakognitif siswa kelas V SD. Model pengembangan yang digunakan dalam penelitian ini adalah model pengembangan 4-D (Four $D$ ). Model ini dikembangkan oleh Thiagarajan yang terdiri atas empat tahap utama yaitu : (1) Pada tahap Define (Pendefinisian) meliputi analisis kebutuhan dengan mengumpulkan berbagai informasi yang diperlukan terkait dengan instrumen yang akan disusun. Berdasarkan analisis kebutuhan yaitu analisis teoretis untuk menemukan indikator dari hasil belajar IPA dan grand teori dari kemampuan metakognitif untuk menyusun kisi-kisi instrumen;

(2) Pada tahap Design (Perancangan) meliputi kegiatan untuk menjabarkan kisikisi menjadi instrumen. Instrumen hasil belajar IPA yang akan disusun berupa tes Pilihan Ganda dengan 4 pilihan jawaban (a, b, c, atau d). Tes pilihan ganda ini terdiri atas keterangan tentang suatu pengertian yang belum lengkap serta satu kemungkinan jawaban benar sesuai dengan kunci jawaban dan beberapa pilihan jawaban pengecoh (Arikunto, 2015). Setiap butir soal (item) akan diberikan skor 1 bila siswa menjawab dengan benar, sedangkan skor 0 untuk siswa yang menjawab salah (pilihan jawaban siswa akan dicocokan dengan kunci jawaban). Tes ini mengkaji tentang penguasaan siswa terhadap muatan materi IPA. Skor setiap jawaban dijumlahkan dan jumlah tersebut merupakan skor variabel hasil belajar IPA. Tes objektif sering disebut tes dikotomi karena jawabannya antara benar atau salah dan peskoran tes objektif antara 0 (nol) dan 1 (satu) (Arifin,2014).

$$
\text { Sedangkan jenis instrumen }
$$

kemampuan metakognitif yang akan disusun berupa tes esai menggunakan rubrik penilaian. Rubrik penilaian digunakan untuk membantu guru memberikan penilaian sesuai dengan capaian pembelajaran. Rubrik penilaian disesuaikan dengan indikator pada soal. Skor setiap jawaban dijumlahkan dan jumlah tersebut merupakan skor variabel kemampuan metakognitif.; (3) Pada tahap Develop (Pengembangan) meliputi kegiatan mengujicoba instrumen yang di design untuk mencari validasi instrumen. Validasi instrumen meliputi validitas isi dan reliabilitas menurut expert. Validitas isi instrumen hasil belajar IPA dan kemampuan metakognitif menggunakan formula CVR dari Lawshe.

Reliabilitas instrumen hasil belajar IPA menggunakan formula KR-20 sedangkan instrumen kemampuan metakognitif menggunakan formula Alpha Cronbach. Pada penelitian ini melibatkan 5 orang expert yang terdiri dari 2 dosen dan 3 praktisi pendidikan dari rekan guru kelas $\mathrm{V}$; (4) Pada tahap Disseminate (Penyebaran) merupakan tahap menyebarluaskan instrumen hasil belajar IPA dan kemampuan metakognitif pada penelitian ini dapat digunakan oleh pihak lain khususnya pada guru kelas $V$ di SD. Namun tahap disseminate pada penelitian ini tidak dapat dilakukan karena adanya karena adanya situasi kesehatan masyarakat yang tidak memungkinkan akibat penyebaran virus corona. Situasi ini menyebabkan pemerintah menghimbau masyarakat agar bekerja dan belajar dari rumah untuk memutus rantai penyebaran virus tersebut.

Metode pengumpulan data merupakan suatu prosedur yang menjelaskan cara perolehan data dalam suatu penelitan. Secara umum metode pengumpulan data dibedakan menjadi dua, yaitu metode tes dan metode nontes (Agung, 2104). Metode nontes terdiri dari (1) metode observasi, (2) metode interview/wawancara, (3) metode kuesioner/angket. Metode pengumpulan data baik dalam bentuk tes maupun nontes mempunyai fungsi masing-masing yang berbeda sesuai dengan jenis metode yang akan digunakan. Perbedaan yang mendasar antara metode tes dan nontes terletak pada jawaban yang diberikan. Dalam tes hanya terdapat kemungkinan jawaban benar atau salah, apabila jawaban tidak sesuai dengan kunci maka jawaban akan dinyatakan salah. Sedangkan dalam metode nontes tidak ada jawaban benar maupun salah, jawaban tergantung pada keadaan seseorang.

Adapun metode pengumpulan data dalam penelitian disajikan pada tabel 1 sebagai berikut. 
Tabel 1. Metode dan Instrumen Pengumpulan Data

\begin{tabular}{llcll}
\hline No & \multicolumn{1}{c}{ Data } & $\begin{array}{c}\text { Metode } \\
\text { Pengumpulan } \\
\text { Data }\end{array}$ & Bentuk Instrumen & \multicolumn{1}{c}{ Validasi Instrumen } \\
\hline 1. & $\begin{array}{l}\text { Instrumen } \\
\text { hasil belajar }\end{array}$ & Tes objektif & Pilihan ganda & $\begin{array}{l}\text { a. Validitas isi } \\
\text { b. Reliabilitas menurut expert }\end{array}$ \\
$\begin{array}{l}\text { IPA } \\
\text { Instrumen } \\
\text { kemampuan } \\
\text { metakognitif }\end{array}$ & Tes subjektif & Esai & $\begin{array}{l}\text { a. Validitas isi } \\
\text { b. Reliabilitas menurut expert }\end{array}$ \\
\hline
\end{tabular}

\section{HASIL DAN PEMBAHASAN}

Hasil pengembangan ini difokuskan pada pengembangan instrumen hasil belajar IPA dan kemampuan metakognitif pada siswa kelas V. Produk yang dikembangkan adalah instrumen berupa soal tes objektif pilihan ganda dan esai. Penelitian ini menggunakan rancangan penelitian dan pengembangan yang dikenal dengan istilah Research and Development (R\&D). Model pengembangan yang digunakan adalah model pengembangan 4D (Four D). Tahapan ini dilakukan secara runtut dan sistematis agar mendapatkan hasil instrumen yang baik.

Pada tahap define dilakukan analisis kebutuhan, analisis teoretik untuk menemukan indikator dari hasil belajar IPA dan grand teori dari kemampuan metakognitif serta menyusun kisi-kisi instrumen. Analisis kebutuhan dengan pegumpulan informasi dan data dilakukan di beberapa sekolah yang berada di wilayah Kota Denpasar. Dari informasi melalui wawancara pada guru dan pengumpulan data tersebut diperoleh bahwa instrumen yang digunakan terbatas pada bank soal maupun soal-soal latihan yang tersedia pada modul siswa. Guru lebih menekankan pada penguasaan konsep IPA dan belum dirancang untuk mengembangkan keterampilan berpikir tingkat tinggi. Instrumen yang telah tersedia tanpa adanya pengembangan oleh guru tersebut memiliki kualitas kurang baik. Terlihat instrumen berada pada ranah kognitif Taksonomi Bloom Revisi terbatas pada C1 (mengetahui) dan C2 (memahami). Sehingga siswa menjadi terbiasa mengerjakan instrumen dengan kemampuan berpikir yang rendah.
Analisis teori dilakukan pada instrumen hasil belajar IPA berpedoman pada Kurikulum 2013 disesuaikan pada standar kompetensi, kompetensi dasar, materi, dan indikator menggunakan dua kompetensi dasar pada semester II yaitu KD 3.8 Menganalisis siklus air dan dampaknya pada peristiwa di bumi serta kelangsungan mahluk hidup dan KD 3.9 Mengelompokkan materi dalam kehidupan sehari-hari berdasarkan komponen penyusunnya (zat tunggal dan campuran). Sedangkan instrumen kemampuan metakognitif menggunakan teori Anderson and Krathwohl Bloom dengan dimensi yaitu pengetahuan strategi, pengetahuan tentang tugas-tugas kognitif dan pengetahuan diri. Berdasarkan analisis teori tersebut, kemudian disusun menjadi kisi-kisi instrumen. Pada penelitian ini instrumen hasil belajar IPA hanya diberikan kepada 5 orang expert yang terdiri dari 2 dosen dan 3 praktisi dengan skala interval. Penilaian oleh expert dilakukan dengan mengisi respon expert yang terdiri 3 rentangan, yaitu relevan, kurang relevan dan tidak relevan.

Pada tahap kedua yaitu design, kisikisi instrumen diimplementasikan menjadi butir instrumen hasil belajar IPA berupa tes objektif pilihan ganda yang pada awalnya berjumlah 55 butir sedangkan instrumen kemampuan metakognitif pada awalnya berjumalah 30 butir. Tahap ketiga yaitu develop, meliputi deskripsi umum masukan expert, hasil uji validitas dan hasil uji reliabilitas. Validasi instrumen meliputi validitas isi dengan expert dan reliabilitas. Validitas isi instrumen hasil belajar IPA dan kemampuan metakognitf menggunakan CVR. Reliabilitas instrumen hasil belajar IPA menggunakan Kuder Richadson (KR- 
20) sedangkan instrumen kemampuan metakognitf menggunakan Alpha Cronbach.

Pada penelitian ini dilakukan sebanyak 1 kali penilian oleh 5 orang expert yang terdiri dari 2 orang ahli dan 3 orang praktisi pendidikan. Instrumen yang telah dibuat melalui proses validasi oleh lima expert. Berikut ini adalah tanggapan umum mengenai soal-soal yang telah dibuat. (1) Rubrik penilaian instrumen kemampuan metakognitif dibuat secara khusus tiap indikator soal dengan kategori yang jelas untuk diukur; (2) Indikator soal pada kisi-kisi yang baik adalah indikator yang spesifik mengandung isi soal; (3) Tambahkan $1 \mathrm{KD}$ dan buatkan soalnya 20-30 butir pada instrumen hasil belajar IPA; (4) Pada indikator kisi-kisi, periksa kembali dimensi pengetahuan yang digunakan; (5) Pada indikator kisi-kisi, periksa kembali dimensi kognitif yang digunakan; (6) Tambahkan soal menjadi $2 x$ lipat dari soal sebelumnya dari setiap indikator pada instrumen kemampuan metakognitif; (7) Tidak perlu ada kunci jawaban pada instrumen kemampuan metakognitif, karena jawaban siswa kemungkinan berbeda-beda. Cukup gunakan rubrik saja; (8) Redaksi soal agar disusun lebih baik; (9) Menentukan contoh pada soal sebaiknya lebih kontekstual; (10) Redaksi soal dalam satu kalimat agar tidak terlalu panjang; (11) Memilih nama daerah dan nama orang disesuaikan dengan lingkungan siswa.Masing-masing expert memberikan penilaian dari aspek materi, bahasa dan konstruksi.

Selanjutnya adalah melakukan uji validitas isi dengan teknik Lawshe, yakni rasio validitas isi atau content validity ratio (CVR). Untuk setiap item, masing-masing pakar menilai apakah item itu "relevan", "kurang relevan", atau "tidak relevan". Validitas isi dengan rumus CVR digunakan pada instrumen hasil belajar IPA dan kemampuan metakognitif. Adapun hasil yang diperoleh disajikan pada tabel 2 .

Tabel 2. Hasil Uji Validitas Isi dan Reliabilitas Instrumen

\begin{tabular}{llcc}
\hline \multirow{2}{*}{ NO } & Instrumen & Uji Validitas Isi & Hasil Analisis \\
& & 50 butir valid & 0,82 \\
\hline 1 & Hasil Belajar IPA & 25 butir valid & 0,78 \\
2 & Kemampuan Metakognitif & & Ujilitas \\
\hline
\end{tabular}

Uji validitas isi instrumen hasil belajar IPA dan kemampuan metakognitif menggunakan teknik Lawshe, yakni rasio validitas isi atau content validity ratio (CVR). Kriteria isi butir dinyatakan valid apabila memiliki CVR $\geq 0,60$. Hasil uji validitas isi instrumen hasil belajar IPA menunjukkan dari 55 butir soal yang dirancang, terdapat 5 butir soal yang tidak valid. Butir soal yang tidak valid tersebut diantaranya: nomor 15 dengan hasil CVR 0,2 nomor 16 dengan hasil CVR -0,2 nomor 28 dengan hasil CVR 0,2 nomor 40 dengan hasil CVR 0,2 nomor 42 dengan hasil CVR 0,2. Sehingga jumlah soal yang valid instrumen hasil belajar IPA terdapat 50 butir soal. Jumlah soal yang valid tersebut selanjutnya dilakukan uji reliabilitas menurut expert dengan menggunakan rumus Kuder Richadson (KR-20). Hasil perhitungan reliabilitas instrumen hasil belajar IPA siswa diperoleh sebesar $r_{11}=0,82$. Karena nilai $r_{11} \geq 0,70$ maka instrumen hasil belajar IPA dinyatakan reliable.

Selanjutnya hasil uji validitas isi instrumen kemampuan metakognitif menunjukkan dari 30 butir soal yang dirancang, terdapat 5 butir soal yang tidak valid. Butir soal yang tidak valid tersebut diantaranya: nomor 5 dengan hasil CVR 0,2 nomor 17 dengan hasil CVR 0,2 nomor 21 dengan hasil CVR 0,2 nomor 28 dengan hasil CVR 0,2 nomor 29 dengan hasil CVR 0,2. Sehingga jumlah soal yang valid instrumen kemampuan metakognitif terdapat 25 butir soal. Jumlah soal yang valid tersebut selanjutnya dilakukan uji reliabilitas menurut expert dengan menggunakan rumus Alpha Cronbach. Hasil perhitungan reliabilitas instrumen kemampuan metakognitif siswa diperoleh 
sebesar $r_{11}=0,78$. Karena nilai $r_{11} \geq 0,70$ maka instrumen kemampuan metakognitif dinyatakan reliable.

Tahap berikutnya setelah memvalidasi adalah Disseminate (Penyebaran). Namun tahap ini tidak bisa dilaksanakan karena situasi kesehatan masyarakat yang tidak memungkinkan akibat penyebaran Virus Corona (COVID19). Khususnya pada lembaga pendidikan yaitu sekolah yang proses belajar dilaksanakan dari rumah (BDR). Situasi ini menyebabkan pemerintah menghimbau masyarakat agar bekerja dan belajar dari rumah untuk memutus rantai penyebaran virus tersebut. Sehingga pada penelitian ini hanya bisa dilakukan sampai pada tahap validasi intrumen menurut expert. Dengan demikian pengembangan instrumen hasil belajar IPA dan kemampuan metakognitif dalam penelitian ini dinyatakan valid dan reliable serta dapat menjadi contoh untuk mengukur serta mengembangkan instrumen hasil belajar IPA dan instrumen kemampuan metakognitif siswa kelas $\mathrm{V}$.

Adanya pengembangan instrumen ini akan menjadikan pengukuran terhadap kemampuan kognitif siswa menjadi lebih optimal. Pengaplikasian tersebut mampu mengembangkan kemampuan pemahaman tingkat tinggi siswa. Serta data yang didapatkan menjadi valid. Hal ini didukung juga dalam penelitian Erniwati (2018) yang menyatakan bahwa instrumen hasil belajar yang baik digunakan setelah melalui beberapa tahap dalam kegiatan pengembangan instrumen. Sejalan dengan pendapat tersebut dalam penelitian Annisa (2017) yang menyatakan bahwa hasil validasi instrumen hasil belajar IPA dikategorikan sebagai produk pengembangan yang tepat digunakan untuk mengukur hasil belajar IPA siswa. Kemudian menurut Ayu (2018) menyatakan bahwa pengembangan instrumen keterampilan belajar dan berinovasi mata pelajaran IPA sangat dibutuhkan oleh siswa SD. Hal ini dikarenakan untuk mengetahui sejauh mana keterampilan belajar dan berinovasi peserta didik,

Asyari (2018) menyatakan bahwa instrumen yang valid dapat digunakan untuk mengkakterisasi kemampuan metakognitif. Sejalan dengan pendapat tersebut Nasution (2019) menyatakan bahwa perangkat pembelajaran yaitu instrumen menggunakan model pembelajaran pendekatan metakognitif memberikan dorongan pada peserta didik untuk belajar, yang pada akhirnya dapat meningkatkan hasil belajar peserta didik.

\section{PENUTUP}

Berdasarkan hasil analisis data dan pembahasan dapat disimpulkan sebagai berikut.

1. Validitas isi instrumen hasil belajar IPA oleh lima orang expert, terhadap 30 butir soal diperoleh hasil yaitu terdapat 25 butir soal yang memenuhi kriteria valid dan 5 butir soal yang tidak valid.

2. Validitas isi instrumen kemampuan metakognitif oleh lima orang expert, terhadap 55 butir soal diperoleh hasil yaitu terdapat 50 butir soal yang memenuhi kriteria valid dan 5 butir soal yang tidak valid.

3. Reliabilitas menurut expert instrumen hasil belajar IPA memperoleh hasil yaitu $r_{11}$ sebesar 0,82 maka instrumen hasil belajar IPA dinyatakan reliable.

4. Reliabilitas menurut expert instrumen kemampuan metakognitif memperoleh hasil yaitu $r_{11}$ sebesar 0,78 maka instrumen kemampuan metakognitif dinyatakan reliable.

Adapun saran yang disampaikan dalam penelitian pengembangan instrumen hasil belajar IPA dan kemampuan metakognitif ini,

1. Saran pemanfaatan untuk guru, instrumen hasil belajar IPA yang telah dikembangkan ini dapat dijadikan tes hasil belajar pada kelas $\mathrm{V}$ semester genap bagi sekolah yang menerapkan Kurikulum 2013 maupun sekolah yang masih menerapkan KTSP pada materi siklus air dan komponen penyusun zat. Guru perlu banyak membaca dan memahami dalam menyusun instrumen yang berkualitas baik. Sehingga penilaian terhadap penguasaan materi siswa lebih bermakna. Penggunaan instrumen ini dapat bersamaan dengan implementasi strategi pembelajaran 
IPA yang inovatif. Instrumen kemampuan metakognitif dapat digunakan guru untuk mengukur kemampuan metakognitif siswa pada muatan materi IPA. Melalui instrumen ini, guru perlu berlatih untuk menciptakan instrumen yang mampu mengembangkan kemampuan metakognitif siswa pada muatan materi lainnya. Siswa harus dibiasakan menghadapi soal yang melibatkan kemampuan metakognitifnya. Taksonomi Bloom Anderson dan Krathwohl Revisi dapat dijadikan pedoman dalam menyusun instrumen kemampuan metakognitif. Dalam penyusunan instrumen hasil belajar IPA dan kemampuan metakognitif, diharapkan tes yang diberikan yaitu kontekstual dan bukan yang bersifat rutin.

2. Saran untuk peneliti lain, instrumen hasil belajar IPA dan kemampuan metakognitif ini dapat digunakan untuk bahan penelitian selanjutnya bagi peneliti lain yang hendak mengukur instrumen hasil belajar IPA dan kemampuan metakognitif siswa. Hasil analisis ini dapat dijadikan contoh pengembangan instrumen dan memberikan masukan pada bidang pendidikan khususnya.

Saran untuk lembaga pendidikan, lembaga pendidikan merupakan wadah tumbuh kembang siswa dengan berbagai proses pendidikan. Sekolah diharapkan mampu mendorong kreativitas guru dan siswa dalam segala bentuk pembelajaran. Dengan adanya kreativitas guru untuk meningkatkan kemampuan peserta didik akan memberikan perubahan yang lebih baik. Dalam perkembangan teknologi dan informasi, perubahan positif tersebut diharapkan dapat mencapai tujuan pendidikan yang lebih optimal.

\section{DAFTAR RUJUKAN}

Agung, A.A.G. 2014. Buku Ajar Metodologi Penelitian Pendidikan. Malang: Aditya Media Publishing.

Anderson and Krathwohl. 2001. A Taxonomy for Learning, Teaching, and Assessing. Published by David McKay Company,Inc. New York:
Addision Wesley Longman, Inc. Diakses tanggal 20 Maret 2020.

Annisa, Mahmuda, dkk. 2017. Pengembangan Dan Uji Coba Instrumen Penilaian Hasil Belajar IPA SMP/MTS Kelas VII Pada Materi Karakteristik Zat. Berkala Fisika Indonesia. No 1, Volume 9, Halaman 8-15. Diakses tanggal 4 Mei 2020.

Arifin, Zaenal. 2014. Evaluasi Pembelajaran : Prinsip, Teknik, Prosedur. Bandung. PT Remaja Rosdakarya.

Arikunto, Suharsimi. 2016. Dasar-dasar Evaluasi Pendidikan. Jakarta. PT Bumi Aksara.

Asyari, Muhammad. 2018. Validitas Instrumen Karakterisasi Kemampuan Metakognisi Mahasiswa Calon Guru Fisika. Jurnal Pengkajian IImu dan Pembelajaran Matematika dan IPA IKIP Mataram. No 1, Volume 6, Halaman 18-26. Diakses tanggal 4 Mei 2020.

Ayu, P. Eka Sastrika. 2018. Pengembangan Instrumen Asesmen Keterampilan Belajar dan Berinovasi pada Mata Pelajaran IPA SD. PENDASI: Jurnal Pendidikan Dasar Indonesia. No 2, Volume 2. Diakses tanggal 27 April 2020.

Erniwati. 2018. Pengembangan Instrumen Penilaian Hasil Belajar IImu Pengetahuan Alam Pada Siswa Kelas V Sekolah Dasar Inpres Loka Kabupaten Bantaeng. Program Studi Penelitian dan Evaluasi Pendidikan Program Pascasarjana Universitas Negeri Makassar. Diakses tanggal 11 Mei 2020.

Ikram, Zul Jalali Wal. 2018. Kegiatan Metakognisi Dalam Pemecahan Masalah Matematika. Makassar, 16 - 17 September 2017. Diakses tanggal 11 Mei 2020. 
Jufri, Wahab. 2017. Belajar dan Pembelajaran Sains: Modal Dasar Menjadi Guru Profesional. Bandung. Penerbit Pustaka Reka Cipta.

Nasution, Iradah Suci Utari. 2019. Pengembangan Perangkat Pembelajaran Matematika Berbasis Pendekatan Metakognitif pada Siswa SMP Muhammadiyah 01 Medan T.P 2019/2020. Seminar Nasional Matematika dan Terapan. Volume 1, Desember. pp: 186-191. Diakses tanggal 3 Mei 2020.

Nugroho, R. Arifin. 2018. HOTS (Higher Order Thinking Skills). Jakarta: PT Gramedia.

OECD. 2015. Programme for International Student Assessment (PISA).

Rusniati, Ni Wayan. 2018. Efektivitas Penerapan Metode Contextual Teaching And Learning Terhadap Peningkatan Hasil Belajar Siswa Dalam Mata Pelajaran IImu Pengetahuan Alam (IPA) Khusus Dalam Materi Sifat-Sifat Cahaya. JIPP. No 3, Volume 2, Halaman 329-335. Diakses tanggal 3 Mei 2020.

Sarini, Ni Komang. 2018. Hasil Belajar IPA Kelas IV SD di Gugus II Santalia Melalui Tutor Sebaya. Jurnal IImiah Sekolah Dasar. No 2, Volume 2, Halaman 94-102. Diakses tanggal 27 April Mei 2020.

Septiasari, P. 2020. Pengaruh Model Reciprocal Teaching Berbasis Pendekatan Saintifik Terhadap Kemampuan Berpikir Kritis dan Hasil Belajar IPA Kelas V. PENDASI: Jurnal Pendidikan Dasar Indonesia. No 1, Volume 4, Halaman 85-94. Diakses tanggal 17 April 2020.

Susanto, Ahmad. 2016. Teori Belajar dan Pembelajaran di Sekolah Dasar. Jakarta. Prenada Media Group.

Udiani, Ni Ketut. 2017. Pengaruh Model Pembelajaran Inkuiri Terbimbing
Terhadap Hasil Belajar IPA Dengan Mengendalikan Keterampilan Proses Sains Siswa $\begin{array}{llll}\text { Kelas IV SD No.7 Benoa } & \end{array}$ Kecamatan Kuta Selatan Kabupaten Badung. e-Journal Program Pascasarjana Universitas Pendidikan Ganesha Program Studi Pendidikan Dasar. No 1, Volume 7. Diakses tanggal $15 \mathrm{Mei}$ 2020.

Wiryawati, W. 2020. Pengaruh Pembelajaran Berpendekatan Saintifik Berorientasi Metakognitif Terhadap Hasil Belajar Matematika Dengan Kovariabel Kemampuan Numerik. PENDASI: Jurnal Pendidikan Dasar Indonesia. No 1, Volume 4, Halaman 105-114. Diakses tanggal 15 Mei 2020.

Wisudawati, Sulistyowati. 2014. Metodologi Pembelajaran IPA. Jakarta. PT Bumi Aksara. 